\title{
Pelatihan Pembuatan Produk Kerajinan Berbahan Cabang Kayu Mangrove
}

\author{
https://doi.org/10.32509/am.v4i1.1319
}

\author{
Ridwanti Batubara ${ }^{1,2}$ Mohammad Basyuni ${ }^{1,2}$, Apri Heri Iswanto ${ }^{1,2}$, Bejo Slamet ${ }^{1,2}$, Arida \\ Susilowati $^{1,2}$, Deni Elfiati ${ }^{1,2}$, Mariah Ulfa ${ }^{1}$, dan Ryzki Pebriansyah ${ }^{3}$ \\ ${ }^{1}$ Program Studi Kehutanan, Fakultas Kehutanan Universitas Sumatera Utara. \\ Jln. Tridharma Ujung No. 1 Kampus USU Medan - Indonesia \\ ${ }^{2}$ Pusat Unggulan Iptek Mangrove, Universitas Sumatera Utara \\ ${ }^{3}$ Program Studi Manajemen Sumberdaya Perairan, Fakultas Pertanian Universitas Sumatera Utara \\ Jln. Prof. A sofyan No. 3 Kampus USU Medan - Indonesia \\ Email Korepondensi: ridwantibb@yahoo.com
}

\begin{abstract}
$\overline{\text { Abstract - Mangrove wood branches are the waste of wood that can be used for various }}$ woodcraft products. The purpose of the training activities carried out is to train people to make handicrafts from mangrove wood branches and to transfer knowledge about the basic characteristics of wood branches in processing The training methods were the provision of training materials, the direct practice making crafts and discussions. The result of the training from the practice of each group was making different crafts from mangrove wood branches, including various key chains, lamp cups and wooden sticks. After the training, the participants gained more knowledge about the basic characteristics of mangrove wood branches and handicraft products from mangrove wood branches.
\end{abstract}

Keywords : mangrove wood branches, training, characteristics of wood, handicraft products

\begin{abstract}
Abstrak - Cabang kayu mangrove merupakan limbah kayu yang bisa dimanfaatkan untuk berbagai produk kerajinan kayu. Tujuan dari kegiatan pelatihan yang dilakukan adalah melatih masyarakat membuat kerajinan berbahan cabang kayu mangrove dan memberikan pengetahuan tentang sifat-sifat dasar cabang kayu dalam pengolahannya. Metode pelatihan meliputi pemberian materi pelatihan, praktek langsung pembuatan kerajinan dan diskusi. Hasil pelatihan dari praktek tiap-tiap kelompok membuat kerajinan dari cabang kayu mangrove yang berbeda-beda, antara lainn aneka gantungan kunci, cup lampu dan tongkat kayu. Setelah pelatihan peserta bertambah pengetahuan tentang sifat-sifat dasar cabang kayu dan produkproduk kerajinan yang dibuat dari cabang kayu.

Kata kunci : cabang kayu mangrove, pelatihan, sifat-sifat kayu, produk kerajinan
\end{abstract}

\section{PENDAHULUAN}

Hutan mangrove yang lebih dikenal sebagai hutan bakau, didefinisikan sebagai tipe hutan yang tumbuh pada daerah pasang surut (terutama pantai yang terlindung, laguna, muara sungai) yang tergenang pada saat pasang dan bebas genangan pada saat surut yang komunitas tumbuhannya bertoleransi terhadap garam (Riwayaty, 2014). Hutan mangrove merupakan eksosistem utama pendukung kehidupan masyarakat pesisir.

Desa Lubuk Kertang, di Kabupaten Langkat memiliki Kawasan Ekowisata Mangrove dan merupakan hutan produksi terbatas oleh Kelompok Tani dan Nelayan Mekar. Selama ini pemanfaatan dan peruntukan hutan hanya untuk kawasan wisata saja. Potensi manfaat tidak akan terancam bila berbasis masyarakat (Dinda dkk., 2018).

Satu diantara potensi pemanfatan non kayu yang berasal dari hutan mangrove atau berupa limbah. Limbah yang mungkin dimanfaatkan dari hutan mangrove ialah limbah ranting dan cabang. Limbah ini biasanya diperoleh dari memangkas cabang-cabang kayu mangrove yang kondisi tajuknya sudah saling bertautan satu dengan yang lain karena rimbun.

Pada Kawasan Wisata Mangrove Lubuk Kertang cabang ranting yang dipangkas khususnya yang berada di sekitar pinggiran jalan menuju lokasi atau di jalur tracking biasanya ditumpuk dan 
dibiarkan begitu saja. Cabang tersebut memiliki potensi untuk diolah menjadi kerajinan, yang dapat dijual di kawasan wisata, sebagai oleh-oleh dari kawasan wisata mangrove. Sehingga akan ada nilai tambah secara ekonomi yang dapat dinikmati oleh pengelola dalam hal ini Kelompok Tani dan Nelayan Mekar.

Namun terdapat permasalahan yaitu kelompok belum mengetahui jenis dan cara membuat kerajianan berbahan limbah kayu mangrove. Untuk mengatasi masalah tersebut maka tim PPM (Pengabdian Pada Masyarakat USU) mengadakan pelatihan pembuatan kerajinan berbahan limbah cabang kayu mangrove. Pemberdayaan masyarakat dan peningkatan pengetahuan bisa dilakukan dengan seminar, pelatihan, sosialisasi, penyuluhan dll (Sujana dkk., 2020). Target dari kegiatan ini adalah meningkatnya pengetahuan dan keterampilan kelompok dalam membuat kerajinan berbahan limbah cabang kayu mangrove. Luaran kegiatan ini adalah produk kerajinan berbahan cabang kayu mangrove. Kegiatan ini juga diharapkan menjadi potensi dan peluang usaha kelompok mitra kedepannya yaitu memproduksi kerajianan berbahan cabang kayu mangrove.

\section{METODE PELAKSANAAN}

Pelatihan kerajinan berbahan cabang kayu mangrove dilakukan pada tanggal 24 Agustus 2020 di workshop kelompok, desa Lubuk Kertang. Pelatihan ini merupakan pelatihan lanjutan dari pelatihan kerajinan berbahan limbah ranting kayu mangrove. Pesertanya yaitu anggota kelompok Tani dan Nelayan Mekar. Pada kegiatan ini dilakukan edukasi sebelum terjun membuat kerajinan berbahan cabang kayu mangrove. Peserta diberikan kuesioner sebelum dan sesudah pelatihan. Pada saat praktik pembuatan kerajinan produk yang dibuat adalah produk sesuai dengan keinginan dan kemampuan peserta untuk membuat dan menyelesaikannya. Pada setiap sesi pelatihan dilakukan tanya jawab dan diskusi untuk memantau pemahaman peserta tentang kegiatan pelatihan yang dilakuan.

\section{HASIL DAN PEMBAHASAN}

Pada pelatihan ini sebelum praktek diberikan materi pelatihan terkait dengan kerajinan yang dibuat dari limbah cabang kayu mangrove. untuk memudahkan diberikan paparan dalam bentuk teori dan aplikasinya (Gambar 1). Terkait dengan teori maka diberikan materi tentang sifat-sifat dasar kayu, karena perbedaan cabang dengan kayu adalah dari sisi diameter kayu saja, dimana diameter cabang lebih kecil dari kayu.

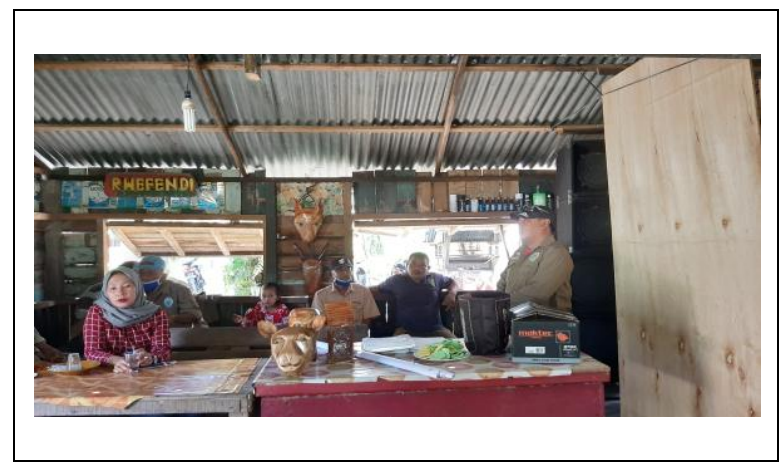

Gambar 1. Suasana Paparan Materi Pelatihan

Sifat-sifat dasar kayu antara lain sifat fisika kayu, sifat kimia kayu dan sifat mekanik kayu. Informasi yang akurat mengenai sifat-sifat dari suatu jenis kayu diperlukan terutama dalam pemilihan bahan baku agar dapat dihasilkan suatu produk yang berkualitas tinggi (Wahyudi dkk., 2014). Berdasarkan pengamatan dan melihat secara fisik maka cabang yang digunakan sebagai bahan baku kerajinan ada 5 jenis cabang kayu mangrove, antara lain nyirih, cingam, teruntun laut, berembang dan tengar.

Pembuatan kerajinan ranting kayu dilakukan dengan terlebih dahulu menentukan produk yang akan dibuat. Pada pelatihan ini kelompok membuat kerajinan dari cabang kayu berupa aneka gantungan kunci dari cabang kayu mangrove (Gambar 2), cup lampu dan tongkat kayu (Gambar 3) serta gantungan baju (Gambar 4). 


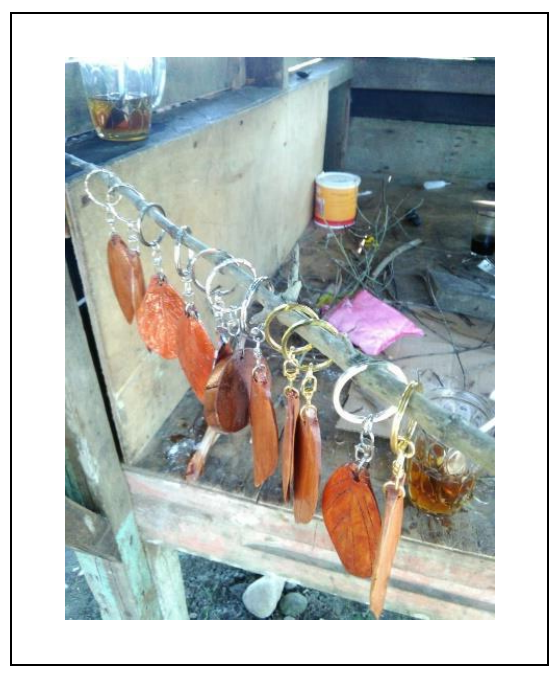

Gambar 2. Aneka GantunganKunci

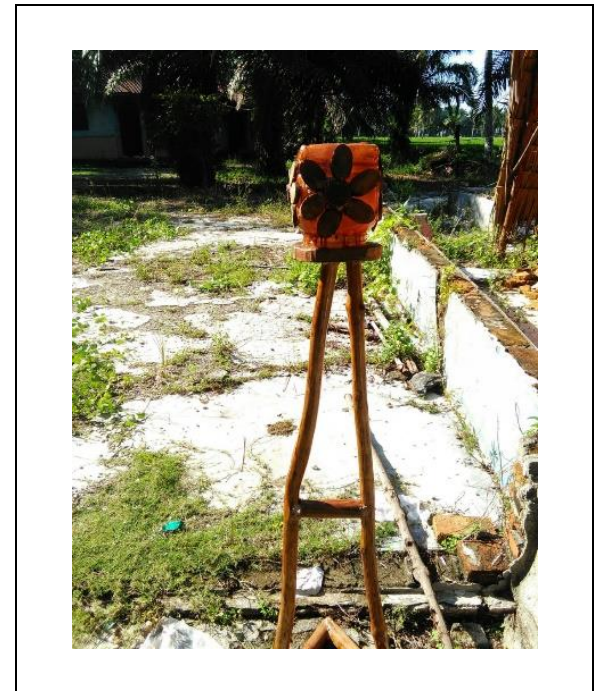

Gambar 3. Cup Lampu dan Tongkat Kayu

Selain dengan membuat produk kerajinan, keberhasilan kegiatan juga diukur dengan melihat peningkatan pengetahuan dari peserta pelatihan, yaitu dengan melihat jawaban para peserta pada kuesioner yang diberikan. Hasil kuisioner dapat dilihat pada Tabel 1.

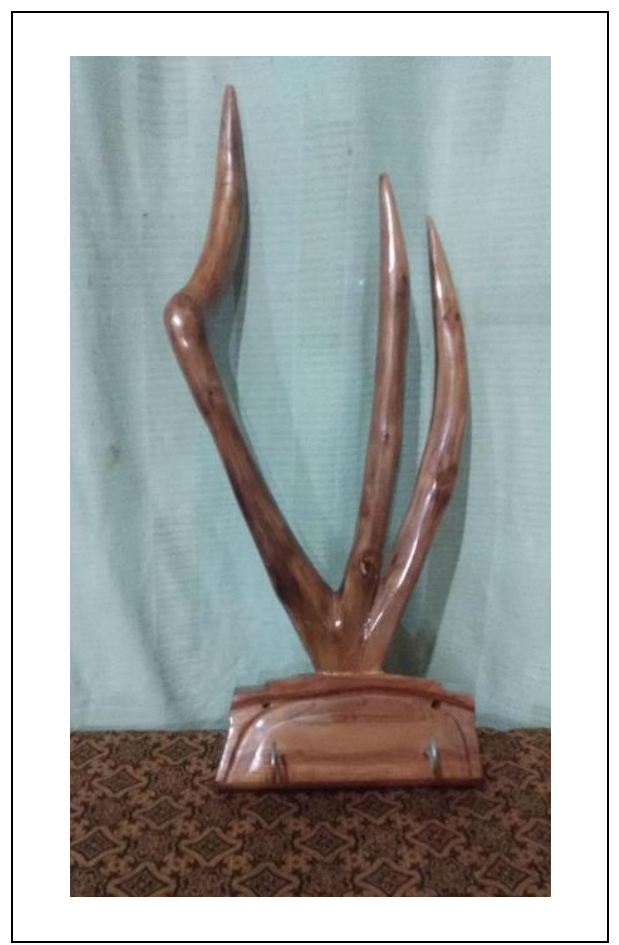

Gambar 4. Gantungan Baju

Tabel 1. Data Kuesioner Sebelum dan Sesudah Pelatihan

\begin{tabular}{|c|c|c|}
\hline Kuisioner & $\begin{array}{c}\text { Sebelum } \\
(\% \text { peserta })\end{array}$ & $\begin{array}{l}\text { Sesudah } \\
\text { (\% peserta) }\end{array}$ \\
\hline $\begin{array}{l}\text { Pengetahuan cabang kayu sebagai } \\
\text { bahan kerajinan }\end{array}$ & $\begin{array}{l}\text { Kurang mengetahui (50), } \\
\text { Mengetahui (50) }\end{array}$ & Ya (100) \\
\hline $\begin{array}{l}\text { Mengikuti kegiatan pelatihan } \\
\text { kerajinan }\end{array}$ & Belum (100) & Ya (100) \\
\hline $\begin{array}{l}\text { Produk kerajinan dari cabang } \\
\text { kayu }\end{array}$ & Souvenir (100) & $\begin{array}{c}\text { Aneka kerajinan bukan } \\
\text { hanya souvenir (gantungan } \\
\text { baju, bonsai, tempat pulpen, }\end{array}$ \\
\hline
\end{tabular}




\begin{tabular}{ccc} 
& & asbak rokok dll (100) \\
\hline $\begin{array}{c}\text { Pengetahuan sifat dasar kayu } \\
\text { Kesulitan dan kemudahan } \\
\text { membuat kerajinan berbahan kayu }\end{array}$ & Tidak (100) & Ya (100) \\
\hline $\begin{array}{c}\text { Akan berinovasi membuat produk } \\
\text { kerajinan dari cabang kayu }\end{array}$ & Belum tahu (0) dan Ya (100) & Ya (100)
\end{tabular}

Berdasarkan data kuisioner bahwasanya semua peserta pelatihan belum pernah mengikuti pelatihan pembuatan kerajinan berbahan dasar cabang kayu. Dengan adanya kegiatan pelatihan ini menambah pengetahuan dan keterampilan mereka dalam membuat kerajinan.

Pada sisi pengetahuan produk yang akan dijadikan kerajinan dari cabang kayu juga terdapat peningkatan pengetahuan peserta, terbukti dari hasil kuisioner jawaban mereka terkait produk yang bisa dibuat menjadi lebih banyak tidak sebatas souvenir saja. Peningkatan pengetahuan ini berdasarkan pengalaman yang tergambar dalam benak dan proses berpikir dari informasi yang telah diberikan pada saat pelatihan.

Dalam membuat produk kerajinan pasti menemukan suka dan duka disamping kesulitankesulitan yang dihadapi. Kesulitan dan kemudahan ini terkait dengan sifat kayu khususnya sifat dasarnya dan sifat pengerjaannya. Sifat pengerjaan kayu berhubungan dengan peralatan atau mesin (Sahri dkk., 2002). Sifat dasar khususnya sifat fisis adalah sifat kayu yang spesifik karena faktor dalam dan faktor luar (Lempeng, 2017). Selain sifat fisis sifat dasar lain adalah sifat mekanis yang juga akan mempengaruhi pada sifat pengerjaan pada pembuatan kerajinan yaitu sifat kekuatannya. Sifat kekuatan tercermit dari sifat fisis yaitu kerapatan atau berat jenis.

Setelah kegiatan pelatihan sesuai dengan harapan bahwa peserta akan berinovasi lagi untuk membuat berbagai produk kerajinan dari limbah cabang kayu, mengingat potensi cabang sangat besar untuk dikembangkan berdasarkan ide-ide dan kreasi yang muncul pada benak peserta. Harapannya setelah pelatihan ini, peserta tidak berhenti membuat kerajinan karena produk yang dibuat sangat potensial untuk dijadikan sebagai produk yang akan dijual di kawasan wisata mangrove.

\section{SIMPULAN}

Kegiatan pelatihan berbahan cabang kayu mangrove yang dilakukan dihasilkan produk aneka gantungan kunci, cup lampu dan tongkat kayu serta gantungan baju. Anggota kelompok bertambah pengetahuannya tentang kerajinan berbahan cabang kayu mangrove dan keterampilan membuat kerajianan berbahan cabang kayu mangrove. Kegiatan pelatihan berbahan limbah cabang kayu mangrove masih membutuhkan pendampingan lanjutan, mengingat waktu pelatihan yang relatif singkat untuk lebih meningkatkan pengetahuan dan keterampilan mereka dalam mengolah limbah cabang kayu menjadi bahan kerajinan

\section{Daftar Pustaka}

Dinda, N., Suadi., dan Sahubawa, L. (2018). Rehabilitasi Ekosistem Mangrove Melalui Proyek Berbasis Masyarakat dan Arus Nilai Ekonomi : Studi Kasus Proyek Rehabilitasi di Desa Lubuk Kertang, Kabupaten Langkat, Sumatera Utara. Jurnal Perikanan Universitas Gadjah Mada, 20 (2), 71-78. https://journal.ugm.ac.id/jfs/article/download/34067/23623

Lempeng, M. (2017). Sifat Dasar dan Kegunaan Kayu Agathis (Agathis hamii M. Dr.) Dari Sulawesi Selatan. Jurnal Penelitian Kehutanan Wallaceae, 6 (2), 157-167. https://media.neliti.com/media/publications/178888-ID-none.pdf

Riwayati. (2014). Manfaat dan Fungsi Hutan Mangrove Bagi Kehidupan. Jurnal Keluarga Sehat Sejahtera, 12 (24), 17-23. https://jurnal.unimed.ac.id/2012/index.php/jkss/article/view/3574

Sahri, M. H., W. T Seng., S. Bokhari. (2002). Machining Properties of Stressed and Non-Stressed Wood of Acacia mangium, Acacia auriculiformis and Havea braziliensis. In: Dwianto W, Editor. Proceeding of the Fourth International Wood Science Symposium. Serpong, 2-5 September 2002. JSPS-LIPI Core University Program. Pp120-125.

Sujana, W. I., W. Al Zarliani., dan Hastuti. (2020). Pemberdayaan Ekonomi Masyarakat Pesisir Melalui Pengolahan Rumput Laut. Jurnal Pengabdian Pada Masyarakat Membangun Negeri, 4(1), 24-33. https://doi.org/10.35326/pkm.v4i1.573 
Wahyudi, M., Makrus, dan A. EB. Suliso. 2014. Sifat Permesinan Dua Jenis Kayu Kurang Dimanfaatkan Asal Papua Barat . Jurnal Ilmu dan Teknologi Kayu Tropis, 12(1), 74-81.

https://media.neliti.com/media/publications/337743-machining-properties-of-two-lesser-used2cd70af0.pdf 